\title{
Bevorderen van prestatiegericht gedrag
}

\section{André de Waal}

SAMENVATTING Hoe kan prestatiegericht gedrag in een organisatie worden bevorderd? Om deze vraag te beantwoorden is onderzocht welke factoren bepalend zijn voor een dergelijk gedrag en welke rol het prestatiemanagementsysteem van een organisatie, zoals de balanced scorecard, daarbij speelt. In de 'prestatiegerichte organisatie', waar voldoende aandacht wordt besteed aan gedragsfactoren, worden betere resultaten behaald doordat organisatieleden op een prestatiegerichte wijze handelen. Dit artikel beschrijft hoe een organisatie kan identificeren, gebruikmakend van de gedragsfactoren, of zij voldoende prestatiegericht is en hoe deze prestatiegerichtheid zou kunnen worden verbeterd.

\section{Inleiding}

In het prestatiemanagementproces komt sturing van de organisatie tot stand door eerst missie, strategie en doelstellingen van de organisatie te bepalen en deze vervolgens systematisch te vertalen naar de onderliggende organisatieniveaus. De organisatiedoelstellingen worden in dit proces meetbaar gemaakt met behulp van kritische succesfactoren (KSF'en) en prestatie-indicatoren (PI'en). Door de resultaten van deze indicatoren regelmatig te rapporteren, zijn snelle bijsturingsacties mogelijk. Daarnaast is een zodanig gedrag van de organisatieleden nodig dat ze regelma-

Dr. A.A. de Waal MBA is zelfstandig adviseur, associate professor strategic management aan de Maastricht School of Management en docent management accounting aan de postdoctorale controllersopleiding van de Universiteit van Amsterdam. (www.andredewaal.nl) Met dank aan mevrouw Drs. B.M.A.A. Schomaker, mevrouw Drs. L. de Waal-Haase en de heer Drs. A. Ardon voor hun kritische commentaar. tig gebruikmaken van het prestatiemanagementsysteem van de organisatie (Lipe en Salterio, 2000; Martins, 2000). De combinatie van dit prestatiegericht gedrag met regelmatig gebruik van het prestatiemanagementsysteem leidt tot verbeterde resultaten (Ahn, 2001; Sandt e.a., 2001; Wiersma, 2001; De Waal, 2002). Het is daarom zaak die factoren te identificeren die de prestatiegerichtheid en het gebruik van het prestatiemanagementsysteem positief beïnvloeden, zodat een organisatie gericht aan het bevorderen daarvan kan werken.

Tijdens een onderzoek (De Waal, 2002) naar deze zogenoemde gedragsfactoren zijn achttien factoren geïdentificeerd die in de praktijk daadwerkelijk een positieve invloed hebben. De term 'gedragsfactoren' wordt hier tweeledig gebruikt: (1) in de zin van handelingen van organisatieleden die kunnen worden geobserveerd en (2) voorwaarden die de organisatie heeft geschapen om het organisatieleden mogelijk te maken een bepaald gedrag te vertonen. De achttien gedragsfactoren zijn te groeperen in vijf gebieden van soortgelijke factoren waaraan een organisatie aandacht moet besteden om de kans te verhogen dat een prestatiemanagementsysteem wordt geïmplementeerd dat regelmatig wordt gebruikt en om prestatiegericht gedrag te stimuleren (zie figuur 1).

De vraag is nu: hoe verkrijgt een organisatie inzicht of er in praktijk voldoende prestatiegericht gewerkt wordt, doordat genoeg aandacht wordt besteed aan de gedragsfactoren? In paragraaf 2 worden de resultaten beschreven van een onderzoek naar de mate waarin een onderzoeksgroep van Nederlandse organisaties prestatiegericht werkt.

In paragraaf 3 worden manieren gegeven die prestatiegericht werken bevorderen. Deze manieren worden op praktische wijze geoperationaliseerd in paragraaf 4 , waarna in paragraaf 5 een korte conclusie wordt gegeven. 


\section{Figuur 1. Gedragsfactoren die belangrijk zijn voor succesvolle implementatie en gebruik van een prestatie- managementsysteem (De Waal, 2002)}

\section{Aandachtsgebied}

Begrip van organisatieleden:

Organisatieleden begrijpen het karakter en het doel van prestatiemanagement

\section{Gedragsfactoren}

1. Organisatieleden begrijpen de betekenis van de Pl'en, waardoor ze inzicht hebben in het (mogelijke) effect van hun handelingen op de resultaten van die PI'en.

2. Organisatieleden onderkennen de relatie tussen de bedrijfsprocessen en de KSF'en en PI'en, waardoor ze begrijpen dat de resultaten die ze behalen op de KSF'en en Pl'en van belang zijn voor de continuïteit van de organisatie.

3. Organisatieleden hebben hetzelfde referentiekader met betrekking tot de Pl'en, waardoor ze onderling hun prestaties kunnen vergelijken en inzicht krijgen in hoe ze ervoor staan ten opzichte van collega's.

4. Organisatieleden zijn het eens met veranderingen in de KSF'en en PI'en, zodat acceptatie ervan gehandhaafd blijft en organisatieleden zich verantwoordelijk blijven voelen voor de resultaten van de (aangepaste) Pl'en.

\section{Houding van organisatieleden:}

Organisatieleden hebben een positieve houding ten opzichte van prestatiemanagement, het prestatiemanagementsysteem en het project

5. Organisatieleden zijn het eens over het moment van aanvang van de invoering van prestatiemanagement, waardoor ze bereid zijn mee te werken.

6. Organisatieleden hebben eerdere (positieve) ervaringen met prestatiemanagement, waardoor ze zich een goed beeld hebben gevormd van het nieuwe systeem en dit beeld ook uitdragen.

7. Organisatieleden onderkennen het belang van KSF'en, PI'en de balanced scorecard (BSC) voor hun eigen functioneren, waardoor het nieuwe systeem onderdeel wordt van de reguliere werkzaamheden.

8. Organisatieleden ervaren KSF'en, Pl'en de BSC niet als bedreigend, waardoor ze niet terughoudend zijn in het gebruik van het nieuwe systeem.

Afstemming van het prestatiemanagementsysteem: Het prestatiemanagementsysteem is afgestemd op de verantwoordelijkheden van organisatieleden

9. De Pl'en van organisatieleden zijn afgestemd op hun verantwoordelijkheidsgebied, waardoor ze relevant zijn voor de aansturing en beheersing van die gebieden.

10. Organisatieleden kunnen de resultaten op hun Pl'en beïnvloeden, wat acceptatie en gebruik van die Pl'en vergroot.

11. Organisatieleden maken hun eigen analyses van de resultaten op de Pl'en, waardoor de kwaliteit van de analyses beter is en ze geaccepteerd worden

12. Organisatieleden kunnen de KSF'en, Pl'en de BSC daadwerkelijk gebruiken voor de aansturing van hun medewerkers, wat regelmatig gebruik van het systeem bevordert.

Organisatiecultuur:

13. Resultaten op PI'en van organisatieleden worden openlijk gecommuniceerd, waardoor iedereen op de hoogte blijft van de status van de organisatie en kennis kan worden gedeeld.

14. Organisatieleden worden gestimuleerd om hun resultaten te verbeteren met behulp van het prestatiemanagementsysteem, waardoor ze niet bang hoeven te zijn te worden 'afgerekend' op basis van de informatie uit het systeem.

15. Organisatieleden kunnen de prestatie-informatie uit het systeem vertrouwen, wat de acceptatie van het systeem vergroot.

16. Organisatieleden zien dat topmanagement het prestatiemanagementsysteem zichtbaar gebruikt, waardoor ze begrijpen dat topmanagement het nieuwe systeem van (groot) belang acht.

Focus van het prestatiemanagementsysteem:

Het prestatiemanagementsysteem heeft een duidelijk intern beheers- en controldoel
17. Organisatieleden vinden het prestatiemanagementsysteem relevant omdat het duidelijk voor interne control is bedoeld en daardoor hun activiteiten daadwerkelijk kan ondersteunen.

18. Organisatieleden vinden het prestatiemanagementsysteem relevant omdat alleen de invloeden van die stakeholders zijn meegenomen die van belang zijn voor het succes van de organisatie, waardoor het systeem gericht blijft op de continuïteit van de organisatie. 


\section{De prestatiemanagementanalyse}

Om de gedragsfactoren, vermeld in figuur 1 , meetbaar en analyseerbaar te maken, is door de auteur de zogenoemde prestatiemanagementanalyse (PMA) ontwikkeld. Dit is een analysemiddel dat voortbouwt op een eerder ontwikkeld analysemiddel, de managementinformatie- en rapportageanalyse (MIRA). De MIRA keek uitsluitend naar de inhoudelijke opbouw van een prestatiemanagementsysteem en in beperkte mate naar het gebruik van dat systeem binnen de organisatie (De Waal e.a., 1998; Van Nimwegen e.a., 2001). De PMA analyseert nadrukkelijk zowel de opbouw en inhoud van het prestatiemanagementsysteem (de systeemkant) als het gebruik van dat systeem door organisatieleden (de gedragskant). De veronderstelling is dat aan beide kanten aandacht moet worden besteed om een prestatiegerichte organisatie te krijgen.
In de PMA zijn de gedragsfactoren uit figuur 1 gecombineerd met criteria uit de MIRA, om tot negen aspecten te komen. Bij de keuze van de aspecten bestaat het probleem dat de literatuur veel empirisch onderzoek naar prestatiemanagementsystemen bevat, maar dat dit (nog) niet heeft geresulteerd in een coherent, algemeen geaccepteerd raamwerk (Groot e. a., 1998; American Productivity \& Quality Center, 1999a, 1999b), op basis waarvan de aspecten zouden kunnen worden gekozen. Het is zelfs de vraag of een 'correcte' terminologie (Von Cotta-Schønberg, 1995) en één perfect raamwerk mogelijk zijn (Moon en Fitzgerald, 1996) omdat elk prestatiemanagementsysteem moet worden angepast aan de specifieke omstandigheden van een organisatie. Om uit deze impasse te komen, zijn de aspecten samengesteld uit groeperingen van elementen die in de onderzoeksliteratuur over prestatiemanagement het meest worden genoemd als belangrijke ingrediënten van een presta-

Figuur 2. De PMA-aspecten en bijbehorende elementen en gedragsfactoren

(N.B. gedragsfactor 5 is niet opgenomen omdat deze alleen speelt bij het bepalen van het invoeringsmoment van prestatiemanagement)

\begin{tabular}{|c|c|c|c|}
\hline PMA-aspect & Soort & Korte beschrijving elementen & Gedragsfactoren \\
\hline Besturingsmodel & Systeem & $\begin{array}{l}\text { Er zijn een duidelijke aansturingstijl en taken en verantwoordelijkheden } \\
\text { gedefinieerd en deze worden consistent toegepast door alle } \\
\text { managementniveaus. }\end{array}$ & - \\
\hline Inhoud & Systeem & $\begin{array}{l}\text { Organisatieleden krijgen een set van financiële en niet-financiële } \\
\text { prestatie-informatie, die een strategische focus heeft door toepassing } \\
\text { van kritische succesfactoren en prestatie-indicatoren. }\end{array}$ & - \\
\hline Integriteit & Systeem & $\begin{array}{l}\text { De prestatie-informatie die wordt geleverd door het } \\
\text { prestatiemanagementsysteem is betrouwbaar, tijdig en consistent. }\end{array}$ & - \\
\hline Hanteerbaarheid & Systeem & $\begin{array}{l}\text { Er worden gebruikersvriendelijke rapporten en systemen gebruikt en de } \\
\text { prestatie-informatie is makkelijk te benaderen via informatietechnologische } \\
\text { systemen. }\end{array}$ & - \\
\hline Verantwoordelijkheid & Gedrag & $\begin{array}{l}\text { Organisatieleden voelen zich daadwerkelijk verantwoordelijk voor de resultaten } \\
\text { van de hele organisatie en van hun eigen prestatie-indicatoren. }\end{array}$ & $2,4,9,10,17,18$ \\
\hline Managementstijl & Gedrag & $\begin{array}{l}\text { Topmanagement is zichtbaar betrokken bij de prestaties van medewerkers en } \\
\text { bevordert een verbetercultuur en pro-actief gedrag; daarbij vertoont } \\
\text { management consequent gedrag in het aanspreken van medewerkers op } \\
\text { hun prestaties. }\end{array}$ & $8,14,15,16$ \\
\hline Actiegerichtheid & Gedrag & $\begin{array}{l}\text { De prestatie-informatie is dusdanig geïntegreerd in de dagelijkse activiteiten } \\
\text { dat problemen onmiddellijk (correctief of preventief) worden aangepakt. }\end{array}$ & $1,7,11$ \\
\hline Communicatie & Gedrag & $\begin{array}{l}\text { Er vindt regelmatige communicatie, top-down en bottom-up, plaats binnen de } \\
\text { organisatie over de prestatie-informatie en er is sprake van regelmatige } \\
\text { uitwisseling van kennis over organisatie-onderdelen heen. }\end{array}$ & 3,13 \\
\hline Afstemming & - & $\begin{array}{l}\text { De andere managementsystemen in de organisatie, zoals het human resource } \\
\text { managementsysteem, zijn afgestemd op het prestatiemanagementsysteem, } \\
\text { zodat op de juiste zaken wordt beoordeeld en beloond. }\end{array}$ & 6,12 \\
\hline
\end{tabular}


tiemanagementsysteem en van prestatiegericht gedrag (onder meer Algera, 2000; Kaplan en Norton, 1996, 2000; Lipe en Salterio, 2000; Malina en Selto, 2000; Marchand e.a., 2000; Massello, 1998; Merchant, 1998; Neely, 1998, 2000; Simons, 1995, 2000; Vosselman, 1999). In figuur 2 zijn de aspecten beschreven en is specifiek aangegeven of het systeem- of gedragsaspecten zijn. Dat er relaties bestaan tussen beide soorten aspecten is onvermijdelijk, maar er is naar gestreefd om een duidelijke scheiding aan te brengen tussen systeemaspecten en gedragsaspecten, zodat beide te analyseren zijn. In de systeemaspecten zijn de elementen ondergebracht die specifiek de opbouw en inhoud van een prestatiemanagementsysteem betreffen, de gedragsaspecten betreffen specifiek het feitelijke gebruik van dat prestatiemanagementsysteem door organisatieleden. In de tabel is verder aangegeven onder welke gedragsaspecten de gedragsfactoren uit figuur 1 vallen.

In de PMA worden de negen aspecten van prestatiegerichtheid gewaardeerd op een schaal van 1 tot en met 10 in een zogenoemd prestatiemanagementradardiagram (figuur 3). Naarmate een organisatie meer aandacht besteedt aan de elementen die horen bij een bepaald aspect, zal zij hoger scoren op dat aspect. De rechterkant van het radardiagram bevat de systeemaspecten, de aspecten aan de linkerkant betreffen de gedragskant. Het radardiagram maakt duidelijk waar een organisatie het eerst aan moet gaan werken om (nog) prestatiegerichter te worden: de 'deuken' in het radardiagram. Daarna dient de organisatie te bepalen in hoeverre zij wil en kan 'opschuiven' op de schaal richting de 10 .

Inmiddels hebben, tijdens workshops en in-companytrainingen gedurende het jaar 2002, managers in leidinggevende posities van 94 Nederlandse organisaties (69 uit de profitsector en 25 uit de non-profitsector) de prestatiegerichtheid van hun eigen organisatie beoordeeld. Dit deden ze met behulp van een vragenlijst waarin per element kan worden aangegeven of de organisatie huns inziens laag of hoog scoort op dat element. Zo is bijvoorbeeld onder het aspect 'Besturingsmodel' het element 'Aansturingsstijl' opge-

Figuur 3. Het 'gemiddelde' prestatiemanagementradardiagram van de deelnemende Nederlandse organisaties

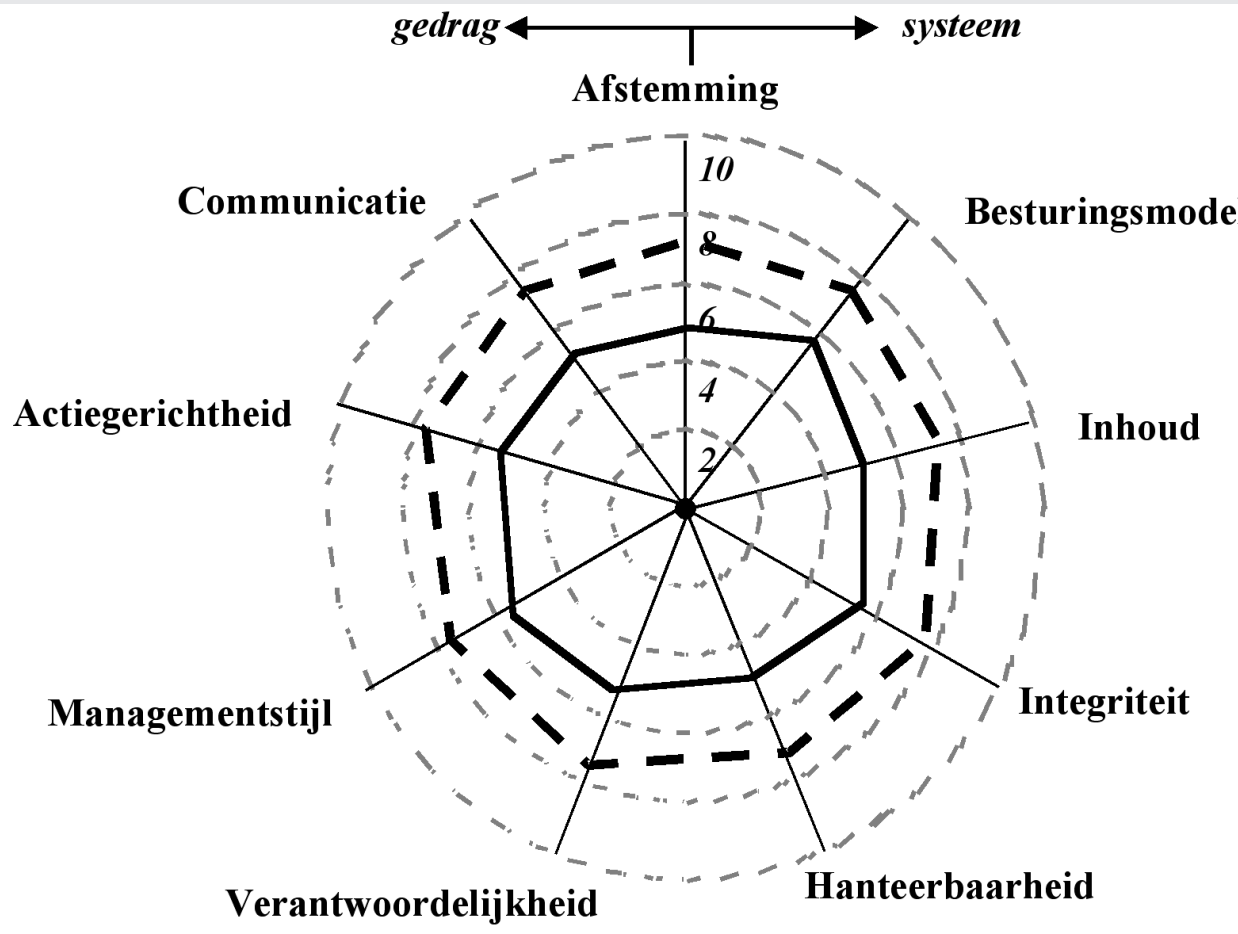


nomen. Hier kan de manager kiezen tussen twee uitersten, met de beschrijvingen 'Aansturingsstijl is onduidelijk, er is (nog) geen (duidelijke) keuze gemaakt met betrekking tot de mate waarin een hoger gelegen organisatieniveau de lager gelegen organisatieniveaus aanstuurt en vrijlaat' (score 1) en 'Aansturingsstijl is duidelijk, er is een duidelijke keuze gemaakt met betrekking tot de manier waarin een hoger gelegen organisatieniveau de lager gelegen organisatieniveaus beheerst en controleert' (score 10). De gemiddelde score van alle elementen onder een aspect geeft de waardering voor dat aspect. Figuur 3 geeft het PMA-radardiagram met de gemiddelde waardering van de managers weer van de huidige prestatiegerichtheid en de door hen gewenste prestatiegerichtheid van hun organisaties.

In het radardiagram is te zien dat de huidige prestatiegerichtheid van de deelnemende organisaties op alle aspecten ongeveer gelijk scoort (rond de 5,5), met een positieve 'uitschieter' voor 'besturingsmodel' $(5,7)$ en een negatieve 'uitschieter' voor 'afstemming' $(5,0)$. Dit geeft aan dat deze organisaties tot nu toe een redelijk gelijkmatige aandacht hebben besteed aan zowel de systeem- als de gedragskanten van prestatiegerichtheid. De relatief betere score voor 'besturingsmodel' kan veroorzaakt zijn doordat onder de deelnemende organisaties er een aantal waren die recent een reorganisatieproces hadden doorgemaakt. In een dergelijk proces wordt vaak het besturingsmodel opnieuw ingericht. De relatief slechtere score voor 'afstemming' geeft aan dat het ingevoerde prestatiemanagementsysteem nog te weinig koppeling heeft met de andere systemen (vooral het HRM-systeem) in de organisatie.

De gelijkmatige aandacht is echter nog verre van optimaal, voor geen van de aspecten is de score hoger dan 6. De deelnemende organisaties onderkennen dat verbetering mogelijk en ook nodig is; in het radardiagram is te zien dat de managers voor de gewenste prestatiegerichtheid een gemiddelde score van ongeveer 7,5 willen bereiken.

\section{3}

\section{Verbetering van de gedragsaspecten}

Als een organisatie een PMA heeft uitgevoerd, kan zij (indien gewenst) overgegaan tot het doorvoeren van verbeteringen. In dit artikel wordt niet ingegaan op hoe de systeemaspecten kunnen worden verbeterd, omdat daarover meer dan voldoende literatuur voorhanden is (zie onder andere Neely, 1998; Kaplan en Norton, 2000; Simons, 2000). Dit artikel concentreert zich op hoe gedragsaspecten kunnen worden verbeterd.

\section{Gedragsaspect: verantwoordelijkheid}

De effectiviteit van het prestatiemanagementsysteem wordt bepaald door de mate waarin organisatieleden zich daadwerkelijk verantwoordelijk voelen voor de resultaten en het systeem willen gebruiken om informatie te krijgen waarmee die resultaten kunnen worden beïnvloed (Euske e.a., 1993). Een sfeer van vrijblijvendheid vormt een wezenlijk risico voor prestatiegerichtheid. De mate waarin men zich verantwoordelijk voelt, is nadrukkelijk iets anders dan de mate waarin men verantwoordelijk wordt gemaakt. Om het verantwoordelijkheidsgevoel te bevorderen, wordt gekeken naar de elementen beheersingsrelevantie en de beïnvloedingsmogelijkheden.

De mate waarin organisatieleden zich verantwoordelijk voelen voor de resultaten, hangt samen met de relevantie van de prestatie-indicatoren voor de beheersing van het eigen verantwoordelijkheidsgebied (Groot, 1997). Hoe relevanter de prestatieindicatoren zijn in de ogen van de organisatieleden, hoe sterker de stimulans voor hen zal zijn om zich in te zetten. Zo zal een operationeel manager zich weinig gestimuleerd voelen tot actie als de prestaties van de organisatie als geheel stagneren. Wanneer inzichtelijk wordt dat zijn afdeling teruglopende prestaties laat zien, zal betrokkene een sterkere stimulans ervaren zijn verantwoordelijkheid te nemen. Dit betekent dat regelmatig bekeken moet worden of de geformuleerde kritische succesfactoren en prestatieindicatoren nog relevant zijn, met andere woorden of ze nog de toestand van het specifieke verantwoordelijkheidsgebied van een medewerker adequaat weergeven. Het kan immers zijn dat er zoveel veranderingen (zowel extern als intern) zijn opgetreden, dat de inhoud van de prestatie-informatie moet worden aangepast.

Het nemen van verantwoordelijkheid voor de prestaties vraagt erom dat de resultaten op het meetniveau daadwerkelijk kunnen worden beïnvloed (Samson \& Challis, 1999). Dat houdt in dat de resultaten van een bepaald organisatieonderdeel of een bepaalde managementlaag door dat onderdeel of die laag moet kunnen worden beïnvloed. Om dit mogelijk te maken, krijgt het organisatielid van hogere managementniveaus de bevoegdheid om effectieve actie te kunnen ondernemen bij problemen in het verantwoordelijkheidsgebied. Dit vraagt ook om betrokkenheid van organisatieleden bij de totstandkoming van de prestatie-indicatoren waarop de resultaten moeten worden behaald (Vosselman, 1999). 


\section{Gedragsaspect: managementstijl}

Een manager met een effectieve stijl stuurt sterk op resultaten, terwijl hij of zij tegelijkertijd ondersteuning geeft aan medewerkers om die resultaten te behalen. Sturing betekent heldere afspraken maken, monitoring, aanspreken op de voortgang en aanspreken op verantwoordelijkheid. Ondersteuning vraagt om een coachende stijl van leidinggeven die gericht is op het vergroten van inzicht in de eigen beïnvloedingsmogelijkheden van medewerkers en het stimuleren van eigen verantwoordelijkheidsgevoel. Beperkt de managementstijl zich tot de sturing, dan ontstaat een directieve stijl met weinig eigen verantwoordelijkheidsgevoel. Beperkt de stijl zich tot ondersteunen en coachen, dan ontstaat vrijblijvendheid en ongerichtheid. De combinatie van resultaatgerichte sturing en coachen komt overeen met 'resultaatgericht coachen' (Schouten en Van Beers, 2000). Om deze managementstijl te bevorderen, wordt gekeken naar de elementen zichtbare betrokkenheid, sturing en ondersteuning.

Onder zichtbare betrokkenheid wordt verstaan dat het management voor de organisatieleden zichtbaar gebruikmaakt van het prestatiemanagementsysteem (Massello, 1998). Zichtbare betrokkenheid gaat daarmee veel verder dan uitgesproken betrokkenheid. Het gaat om concreet gedrag waaraan organisatieleden kunnen zien dat hun manager werkelijk betrokken is. In de formele context blijkt deze betrokkenheid uit het feit dat managers tijdens managementteammeetings en afdelingsoverleggen prestatie-informatie gebruiken om de voortgang, problemen en verbeteracties te bespreken. Informeel gezien blijkt betrokkenheid uit regelmatige interesse voor de voortgang die bereikt is door organisatieleden en voor het verloop van hun verbeteracties, maar ook uit het zelf tijd investeren in het zichtbaar behalen van resultaten. De voorbeeldrol van het management is essentieel. Alleen als het management voortdurend laat merken dat zij prestatie-informatie serieus neemt en acties daarop baseert, zullen organisatieleden zich voldoende inzetten voor de gewenste prestaties.

Om de aandacht van organisatieleden maximaal te richten op de te behalen resultaten, is krachtige sturing van management noodzakelijk. Sturing kenmerkt zich door het stellen van heldere doelen en verbeterplannen en door de discipline om de voortgang op gezette tijden te monitoren en (aanvullende) verbeteracties te (laten) formuleren (Mastenbroek, 1997). Om vrijblijvendheid te voorkomen, moet de manager medewerkers durven aan te spreken op pres- taties die achterblijven en op hun verantwoordelijkheid daarvoor. Daarnaast dient de manager ook verbeteringen die zijn behaald door medewerkers op te merken en deze zichtbaar te waarderen.

Terwijl de sturing met name gericht is op het aanspreken op verantwoordelijkheid, is ondersteuning gericht op het stimuleren van het eigen verantwoordelijkheidsgevoel. Het eenzijdig opleggen van doelen en het 'botweg' confronteren met te lage prestaties zal het eigen verantwoordelijkheidsgevoel van organisatieleden doorgaans niet stimuleren. Dit vraagt om een coachende stijl die gericht is op het laten nadenken van organisatieleden over hun eigen beïnvloedingsmogelijkheden (Ardon, 1999). Dit vraagt onder meer om, tijdens het formuleren van gewenste prestaties, het betrekken van de organisatieleden. Vervolgens is het van belang bij voortgangsbesprekingen de organisatieleden, door de gebruikte vraagstelling, na te laten denken over wat er in hun gedrag voor heeft gezorgd dat de prestaties wel of niet zijn gehaald, om hen er vervolgens ook zelf over na te laten denken welke mogelijkheden ze zien om de prestaties zelf positief te beïnvloeden. Dit vraagt om een nadrukkelijk andere stijl dan te vragen naar rationalisaties ('hoe komt het dat ...'), aangezien die het afschuiven van eigen verantwoordelijkheid op andere organisatieleden of externe factoren juist stimuleren.

\section{Gedragsaspect: actiegerichtheid}

Actiegerichtheid betreft de mate waarin prestatieinformatie daadwerkelijk leidt tot acties die gericht zijn op verbetering van de prestaties (Pfeffer \& Sutton, 2000). Actiegerichtheid is een goede voorspeller van de effectiviteit waarmee prestatiemanagement wordt ingezet. Immers, indien de prestatie-informatie niet leidt tot acties, is de toegevoegde waarde van die informatie nihil. Om de actiegerichtheid te bevorderen, wordt gekeken naar de elementen integratie, correctief actiemanagement en preventief actiemanagement.

Integratie heeft betrekking op de mate waarin de prestatie-informatie is geïntegreerd in de dagelijkse bedrijfsvoering. Wanneer van een goede integratie sprake is, wordt prestatie-informatie door de organisatieleden gezien als onmisbaar om 'het gewone werk' goed te doen. Dit betekent dat de informatie als basis dient voor besluitvorming en een vaste plaats heeft in besluitvormingsprocessen (Gelderman, 1998). Hiervoor is het nodig dat de managementrapportageset standaard een exceptie-, analyse- en actierapportage bevat, waarvan bovendien de bespreking een vast agendapunt vormt tijdens het managementteam- en afdelingsoverleg (Davenport, 2000). 
Correctief actiemanagement betekent dat organisatieleden onmiddellijk correctieve acties ondernemen om achterblijvende prestaties alsnog positief te beïnvloeden. Dit vraagt om het consequent zichtbaar maken van de prestatie-informatie, regelmatig de voortgang monitoren en analyseren hoe de prestaties te verbeteren zijn. Vervolgens dient voor alle organisatieleden zichtbaar te zijn welke actie(s) door wie en wanneer worden ondernomen. Ten slotte behoort een consequente evaluatie plaats te vinden van de correctieve acties.

Preventief actiemanagement heeft betrekking op het preventief corrigeren (Rigas en Fan, 2000). Hiervoor is een voortschrijdende prognose (rolling forecast), bijvoorbeeld over vier tot zes kwartalen, noodzakelijk. Goed preventief actiemanagement maakt zichtbaar waar stagnaties in de prestaties zijn te verwachten, waarop vervolgens acties worden genomen om die bij voorbaat te corrigeren. Evenals bij correctief actiemanagement is helder inzicht voor organisatieleden nodig in de acties, alsmede wie waarvoor verantwoordelijk is. Evaluatie van de acties is ook nu noodzakelijk. Door te beschikken over een standaardanalyseen actierapportage worden de te ondernemen acties, hun verloop en hun resultaat inzichtelijk voor de organisatieleden. Besprekingen van deze rapportage richten zich niet op het waarom van achterblijvende resultaten, maar op de kwaliteit van de analyses en acties en op de vraag of anvullende acties nodig zijn.

\section{Gedragsaspect: communicatie}

Om prestatiemanagement goed te laten functioneren, is optimale communicatie noodzakelijk over de richting (strategie) van de organisatie, de kaders waarbinnen organisatieleden mogen en kunnen opereren, de te behalen en behaalde prestaties en de opgedane leerervaringen. Communicatie en afstemming is nodig om organisatieleden vanuit dezelfde referentiekaders naar de prestatie-informatie te laten kijken, zodat iedereen hetzelfde verstaat onder die informatie. Om de communicatie te bevorderen, wordt gekeken naar de elementen top-down communicatie, bottom-up communicatie, horizontale uitwisseling en beeldvorming.

Top-down communicatie omvat twee elementen: feed forward en feedback. Bij feed forward geeft de top van de organisatie de gemeenschappelijke richting van de organisatie aan door helder te communiceren over de strategie, de te behalen prestaties en de prioriteiten. Op deze manier weten organisatieleden waar de organisatie in de toekomst naartoe wil en kunnen ze een betrokkenheid daarmee voelen. Bij feedback koppelt de top, na consolidatie van de prestatie-informatie vanuit de hele organisatie, een helder beeld terug naar de organisatieleden over de behaalde resultaten. Daarbij wordt nadrukkelijk aan separate organisatieonderdelen aangegeven wat hun bijdrage was aan het grote geheel (Economist Intelligence Unit, 1994). Op deze manier weten organisatieleden hoe de organisatie ervoor staat en kunnen ze een betrokkenheid daarmee voelen.

Bottom-up communicatie omvat eveneens de twee elementen feed forward en feedback. Bij feed forward komt planningsinformatie lager uit de organisatie gestructureerd naar de top, zodat deze het beleid en de strategie daarop kan baseren. Het verwerken van deze informatie in het beleid vergroot het draagvlak voor dat beleid. Deze informatiestroom heeft in de praktijk een 'afstemmingskarakter' met de top-down informatiestroom. Bij feedback koppelen de lagere niveaus in de organisatie de door hen behaalde prestaties gestructureerd terug naar de top, zodat deze goed weet hoe de organisatie ervoor staat. Zowel topdown- als bottom-up-communicatie vragen om een heel bewust vormgegeven communicatiestructuur. $\mathrm{Bij}$ voorkeur sluit deze nauw aan bij de reeds bestaande overlegvormen, teneinde prestatiemanagement maximaal aan te laten sluiten bij de bestaande organisatie. Hiervoor is een positieve cultuur nodig die zich niet richt op 'afrekenen' op resultaten, maar op continue verbetering. Daarbij worden organisatieleden wel aangesproken op de behaalde resultaten, maar met het uitdrukkelijke doel te bespreken hoe deze kunnen worden verbeterd.

Regelmatige horizontale uitwisseling van prestatieinformatie tussen organisatie-onderdelen leidt tot een vergroot inzicht van de waarde van de eigen prestaties. Wanneer bovendien onderling inzicht wordt verschaft in de problemen en de lessons learned, zal een proces van onderling leren over prestatiegericht werken worden gestimuleerd. Dit proces verloopt bij voorkeur via speciale uitwisselingsbijeenkomsten, omdat 'papieren informatie' in de praktijk te vrijblijvend is. Hiervoor is een cultuur nodig die kennisuitwisseling niet alleen aanmoedigt, maar ook beloont (Senge, 1994; Choo, 2000).

\section{De prestatiemanagementanalyse bij Tempo Team Werknet}

Een kort voorbeeld van de operationele eenheid Werknet Noord-Oost Nederland van uitzendbureau Tempo Team illustreert de werking van de PMA in de praktijk. Bij deze organisatie leefde sterk de vraag hoe prestatiegericht deze is, nu inmiddels twee jaar vers- 
treken zijn sinds een nieuwe organisatiestructuur was neergezet. Hierbij zijn toentertijd nieuwe taken, bevoegdheden en verantwoordelijkheden gedefinieerd en gecommuniceerd en werd een nieuw prestatiemanagementsysteem geïmplementeerd. De daarin opgenomen prestatie-indicatoren vormen nu het uitgangspunt om de prestaties van medewerkers te volgen. $\mathrm{Na}$ al deze veranderingen was de vraag of de medewerkers daadwerkelijk het door Tempo Team Werknet gewenste prestatiegerichte gedrag vertonen. Dit is des te belangrijker omdat in de huidige economische situatie de concurrentie op de uitzendmarkt zeer sterk is, waardoor de prijzen permanent onder druk staan. Het management van Tempo Team Werknet - Regio Noordoost besloot om de PMA uit te voeren, om antwoord op deze vraag te krijgen.

Er werd een dag georganiseerd tijdens welke alle managers van de regio Noordoost de PMA hebben ingevuld. De gemiddelde scores van alle PMAs werden in het prestatiemanagementradardiagram gezet dat vervolgens door de aanwezige managers is besproken. Nadrukkelijk werd hierbij aandacht besteed aan mogelijke verbeteringen voor 'deuken', hoe deze aan te pakken en hoe om te gaan met eventuele barrières die de verbeteringen zouden kunnen blokkeren. Uit de discussie kwamen concrete verbetertrajecten naar voren. Een voorbeeld is het traject dat werd geformuleerd om het aspect 'communicatie' te verbeteren. In de PMA scoorde dit aspect relatief minder dan de andere aspecten, terwijl het aspect 'actiegerichtheid' juist beter scoorde. Na discussie bleek dat binnen de operationele eenheid veel kennis en ervaring aanwezig is, maar dat dit te weinig gestructureerd wordt uitgewisseld. Het gevolg is dat bij bepaalde problemen die optreden in een deel van de organisatie, dit deel onmiddellijk actie onderneemt (omdat de organisatie zo sterk actiegericht is), zonder zich ervan bewust te zijn dat een ander deel van de eenheid al ervaring had opgedaan met dit probleem en er een mogelijke oplossing voor had. Besloten werd de communicatie en kennisdeling gestructureerder op te zetten met behulp van een nieuwsbrief (die niet wordt gevuld door stafmedewerkers maar door de lijnmanagers zelf) en door het organiseren van regelmatige themabijeenkomsten. Deze acties zijn inmiddels uitgevoerd en beginnen hun eerste positieve resultaten op te leveren. Over enige tijd zal de PMA worden herhaald bij de operationele eenheid om te zien of de organisatie daadwerkelijk beter scoort op het aspect 'communicatie'. Andere eenheden van Tempo Team zijn nu ook van plan de PMA uit te voeren.

\section{Beschouwing en conclusie}

Het PMA-onderzoek onder 94 Nederlandse organisaties kent een aantal beperkingen. De eerste is dat de onderzoekspopulatie niet noodzakelijkerwijs representatief is voor 'de' Nederlandse organisatie. De tweede is dat de deelnemende managers hun organisaties wellicht positiever hebben beoordeeld dan dat (objectieve) onderzoekers dat zouden hebben gedaan. Tot slot is het denkbaar dat er nog andere gedragsfactoren zijn, niet opgenomen in de PMA, die van wezenlijk belang zijn voor de prestatiegerichtheid van een organisatie.

Ondanks deze beperkingen geeft het onderzoek een interessant eerste beeld van de prestatiegerichtheid van Nederlandse organisaties. Dit beeld wijst erop dat deze redelijk gelijkmatig aandacht besteden aan zowel de systeem- als de gedragskant van prestatiegerichtheid. Tegelijkertijd is nog (veel) verbetering mogelijk, voor geen van de aspecten is de score immers hoger dan 6. De organisaties hebben blijkbaar nog onvoldoende rendement kunnen halen uit de tot dusver uitgevoerde verbeteringsprojecten (zoals het invoeren van een balanced scorecard) en streven daarom naar nog verdergaande verbetering, zowel aan de structuurkant als de gedragskant. Uit de eerste praktijkervaringen met de PMA blijkt dat deze daadwerkelijk aanzet tot verbetering. Dit komt mede doordat de PMA inzichtelijk maakt wat managers zelf vinden van de prestatiegerichtheid van hun organisatie, waardoor het draagvlak voor de analyseresultaten groot is. Ook eventuele verschillen van inzicht tussen managers komen door de PMA nadrukkelijk naar voren. Het blijkt de managers uiteindelijk niet te gaan om de absolute scores in het radardiagram, maar om de relatieve 'deuken' en de daarop volgende discussie over hoe deze te verbeteren.

\footnotetext{
Literatuur

Ahn, H., (2001), Applying the balanced scorecard concept: an experience report, in: Long Range Planning, 34, pp. 441-461.

Algera, J.A., (2000), Performance management in organisaties, tien jaar ervaring met ProMES, in: Bedrijfskunde, 2, pp. 14-19.

American Productivity \& Quality Center, (1999a), Performance management: tapping your organization's people potential, APQC Report.

American Productivity \& Quality Center, (1999b), Achieving organizational excellence through the performance measurement system, APQC Report.

Ardon, A., (1999), Klantgestuurde teams, ontwerp, besturing en ontwikkeling, Uitgeverij Contact, Amsterdam.

Choo, C.W., (2000), Closing the cognitive gaps: how people process information, in: D.A. Marchand, T.H. Davenport en T. Dickson (red.), Mastering information management, complete MBA companion in information management, Prentice Hall Financial Times, Harlow, pp. 245-253.
} 
Cotta-Schønberg, M. von, (1995), Performance measurement in the context of quality management, key paper presented at the First Northumbria Conference on Performance Measurement, Internet.

Davenport, T.H., (2000), Attention: the next information barrier, in: D.A. Marchand, T.H. Davenport en T. Dickson (red.), Mastering information management, complete MBA companion in information management, Prentice Hall Financial Times, Harlow, pp. 46-51.

Economist Intelligence Unit, (1994), The new look of corporate performance measurement, research report, London.

Euske, K.J., M.J. Lebas en C.J. McNair, (1993), Performance management in an international setting, in: Management Accounting Research, 4, pp. 275-299.

Gelderman, M., (1998), De mythe van niet-financiële prestatiemeting, in: Tijdschrift Controlling, 12, pp. 34-37.

Groot, T.L.C.M., (1997), De ontwikkeling van management accounting theorie en praktijk, in: Maandblad voor Accountancy en Bedrijfseconomie, 71, 3, pp. 96-104.

Groot, T.L.C.M., J. van der Meer-Kooistra en M.J.F. Wouters, (1998), Dynamiek en dilemma's rond prestatiemeting, van confectie naar maatwerk, in: Tijdschrift BedrijfsAdministratie, 102, 1216, pp. 346-349.

Jansen, P.G.W. en A.A. de Waal, (2002), Prestatiemanagement van commitment: kan dat?, in: Bedrijfskunde, 74, 4, pp. 31-37.

Kaplan, R. S. en D.P. Norton, (1996), The balanced scorecard, translating strategy into action, Harvard Business School Press, Boston, Mass.

Kaplan, R.S. en D.P. Norton, (2000), The strategy-focused organization, how balanced scorecard companies thrive in the new business environment, Harvard Business School Press, Boston, Mass.

Lipe, M.G. en S.E. Salterio, (2000), The balanced scorecard: judgmental effects of common and unique performance measures, in: Accounting Review, 75, 3, pp. 283-298.

Malina, M.A. en F.M. Selto, (2000), Communicating and controlling strategy: an empirical study of the effectiveness of the balanced scorecard, paper presented at the AAA Annual Conference, Philadelphia, August 13-16.

Marchand, D.A., T.H. Davenport en T. Dickson (red.), (2000), Mastering information management, complete MBA companion in information management, Prentice Hall Financial Times, Harlow.

Martins, R.A., (2000), Use of performance measurement systems: some thoughts towards a comprehensive approach, in: A. Neely (red.), Performance measurement - past, present, and future, Centre for Business Performance, Cranfield University, Cranfield, pp. 363-370.

Massello, C.S., (1998), How to succesfully implement strategic planning, in: Journal of Modern Business, Internet, http://www.dcpress.com/jmb/ jmb1998.htm.

Mastenbroek, W.F.G., (1997), Verandermanagement, Holland Business Publications, Heemstede.

Merchant, K.A., (1998), Modern management control systems: text \& cases, Prentice Hall, Upper Saddle River, NJ.

Moon, P. en L. Fitzgerald, (1996), Delevering the goods at TNT: the role of the performance measurement system, in: Management Accounting Research, 7, pp. 431-457.

Neely, A., (1998), Measuring business performance, why, what and how, The Economist Books, London.

Neely, A. (red.), (2000), Performance measurement - past, present, and future, Centre for Business Performance, Cranfield University, Cranfield.
Nimwegen, H. van, T.L.C.M. Groot, H.B.A. Steens en F.A. Roozen, (2001), Ontwikkelingen in financieel management, in: Tijdschrift Financieel Management, november/december, pp. 85-89.

Pfeffer, J. en R.I. Sutton, (2000), The knowing-doing gap, how smart companies turn knowledge into action, Harvard Business School Press, Boston, Mass.

Rigas, J. en I.S. Fan, (2000), Devising improvement action plans out of performance measurement by an operational model of performance indicators, in: A. Neely (red.), Performance measurement - past, present, and future, Centre for Business Performance, Cranfield University, Cranfield, pp. 483-490.

Samson, D. en D. Challis, (1999), Patterns of excellence, the new principles of corporate success, Prentice Hall Financial Times, Harlow.

Sandt, J., U. Schaeffer en J. Weber, (2001), Balanced performance measurement systems and manager satisfaction, Otto Beisheim Graduate School of Management.

Schouten, J. en W. van Beers, (2000), Resultaatgericht managen, Thema, Zaltbommel.

Senge, P.M., (1994), The Fifth Discipline, Currency Doubleday, New York.

Simons, R., (1995), Levers of control, how managers use innovative control systems to drive strategic renewal, Harvard Business School Press, Boston, Mass.

Simons, R., (2000), Performance measurement and control systems for implementing strategy: text \& cases, Prentice Hall, Upper Saddle River, NJ.

Vosselman, E.G.J., (1999), Accounting en gedrag: zichtbare en onzichtbare effecten van management accounting, Kluwer, Deventer.

Waal, A.A. de, J.H.J.M. Mijland-Bessems en H. Bulthuis, (1998), Meten Moet!, Kluwer Bedrijfsinformatie, Deventer.

Waal, A.A. de, (2002), Quest for Balance, the human element in performance management systems, John Wiley \& Sons, New York.

Waal, A.A. de en A. Ardon, (2002), Hoe prestatiegedreven zijn Nederlandse organisaties?, M@n@gement,www.managementsite.nl, januari.

Wiersma, E., (2001), De balanced scorecard: wetenschappelijke onderzoekresultaten, in: Handboek Management Accounting, Kluwer, Deventer 